\title{
Role of MIB-1 Labeling Index in Differentiating Grade II and Grade III Astrocytomas
}

\author{
Srikanth Umakanthan ${ }^{1 *}$, Maryann Margaret Bukelo ${ }^{2}$, Ramadas Naik ${ }^{3}$ and Sharada Rai ${ }^{4}$ \\ ${ }^{1}$ Department of Pathology, The University of the West Indies, Trinidad \\ ${ }^{2}$ Department of Pathology, Eric Williams's medical science complex, Trinidad \\ ${ }^{3}$ Department of Pathology, Yenepoya Medical College, India \\ ${ }^{4}$ Department of Pathology, Kasturba Medical College, India
}

Submission: August 07, 2017; Published: August 17, 2017

*Corresponding author: Srikanth Umakanthan MBBS, MD-Pathology, Consultant/Lecturer, The University of the West Indies, St Augustine, Trinidad, Tel: 18686452640; Email: Srikanth.Umakanthan@sta.uwi.edu

Abstract

Aim: Tumor grading is a significant predictor for clinical outcome of astrocytomas. The aim of the present study is the application of MIB-1 labeling index (LI) in differentiating Grade II and Grade III astrocytomas.

Methods: Our study included 50 cases of astrocytomas. MIB-1 LI was done in all cases and was compared in correlation with 2007 World Health Organization classification.

Result: The mean MIB-1 LI for Grade II astrocytomas was $3.07 \pm 2.51$ and $12.04 \pm 4.66$ in Grade III astrocytomas. P values were significant between Grade II and Grade III astrocytomas.

Conclusion: MIB-1LI is used as an effective tool in assessing astrocytic tumor proliferation and also as an important prognostic indicator supplementing the standard histopathological assessment. Present study demonstrates the usefulness of MIB-1LI in Grade II and Grade III astrocytic tumors where histopathologic grading becomes difficult based solely on morphology.

Keywords: Astrocytoma; MIB-1 Labeling index; Tumor grade

\section{Introduction}

Astrocytomas constitute majority of primary intra cerebral tumors [1]. Tumor grading is a useful prognostic predictor in astrocytomas. The low- grade tumors are associated with better prognosis in comparison to high grade tumors. However, when small stereotactic guided biopsies are obtained, differentiation based only on morphology may be difficult and confusing. Therefore, MIB-1 Labeling index (LI) which determines the proliferation in astrocytomas have an important role to measure the diagnostic and prognostic clinical outcome [2].

MIB-1 antibody is an IgG1 class monoclonal antibody which recognizes a core antigen present in the nuclei of the cells in all phases of the cell cycle except in the resting phase [3]. World Health Organization (WHO) however does not include MIB-1 LI as a component in grading scheme for gliom as [4]. The cellular proliferation is related to tumor growth rate, quantification of this process has prognostic value and is related to tumor grading. The LI of any of the proliferating antigens is the number antigen positive cells divided by total number of cells sampled microscopic areas of the tumor. Ki67 are nuclear antigens that appear during the proliferative phases of the cell cycle [5]. Therefore proliferation rate can be assessed by measuring Ki67 labeling index using MIB-1 antibody. Hence MIB-1 is used in differentiation between diffuse and anaplastic astrocytomas.

This study signifies the importance of MIB-1LI in the assessment of Grade II and Grade III astrocytomas in correlation with histopathologic grading of astrocytomas based on WHO classification.

\section{Materials and Methods}

This study includes 50 patients diagnosed with Grade II and Grade III astrocytic tumors based on WHO classification of central nervous system (CNS) tumors over a period of four years from January 2007 to December 2010.

The specimens were processed by routine paraffin embedding technique. All the specimens were from biopsy of operated tumors. Paraffin sections of 3-5 $\mu$ were obtained from 


\section{Juniper Online Journal of Case Studies}

each block and stained with hematoxylin and eosin (H and E). The tumors were graded according to the WHO classification of CNS tumors.

Our study included 29 patients of Grade II astrocytomas and 21 patients of Grade III astrocytomas which were analysed for MIB-1 LI by polymer labeling two step method using super sensitive polymer-Horseradish peroxidase (HRP).

MIB-1 (Ki-67 specific monoclonal antibody; BGX-297) Mouse monoclonal was used. Cases with small tissue size were not included in our study. Positive control used was Lymphoma. Immuno staining was evaluated at low power in tumor areas having the greatest number of immune reactive cells. Only nuclear staining was regarded positive.

The MIB-1 LI was indicated as the percentage of tumor cell nuclei stained, in areas of maximum staining and calculated in at least 1000 cells using a high power (40x) objective.

Survival data for length of survival was obtained for 33 patients over a period of 35 to 55 months and was evaluated based on the information obtained from clinical records on subsequent follow up. In the present study, a p value of $<0.05$ was considered significant for the performed tests. The ethical clearance was obtained prior to the study.

\section{Results}

In the present study, age group ranged from 0 to 60 years. Third decade constituted the majority of the cases $(50.54 \%)$ with male preponderance and male: female ratio of 1.4:1.

The majority of astrocytomas occurred in the middle cranial fossa (52\%). Grade II astrocytomas constituted of 29 cases and mainly consisted of fibrillary type. On histopathology they were composed of fibrillary neoplastic astrocytes loosely woven together with mild degree of nuclear pleomorphism. Mitotic activity, necrosis and microvascular proliferation were absent.

Grade III astrocytomas or anaplastic type constituted of 21 cases and were characterized by increased cellularity, moderate nuclear pleomorphism, presence of mitotic figures, significant vascular proliferation and microcystic changes.

Table 1: Mean MIB-1 LI with SD, median and rage between Grade II and Grade III astrocytomas. SD: Standard Deviation; LI: Labeling Index.

\begin{tabular}{|c|c|c|c|}
\hline Astrocytomas & MIB-1 LI (with SD) & Median & Range \\
\hline Grade II & $3.07 \pm 2.51$ & 0.6 & $0.4-12$ \\
\hline Grade III & $12.04 \pm 4.66$ & 5.2 & $8-16.4$ \\
\hline
\end{tabular}

MIB-1 LI was significantly increased with the grade of astrocytoma. The mean MIB-1LI with a standard deviation along with median and range in Grade II and Grade III astrocytomas were analysed (Table 1) (Figure $1 \& 2$ ).

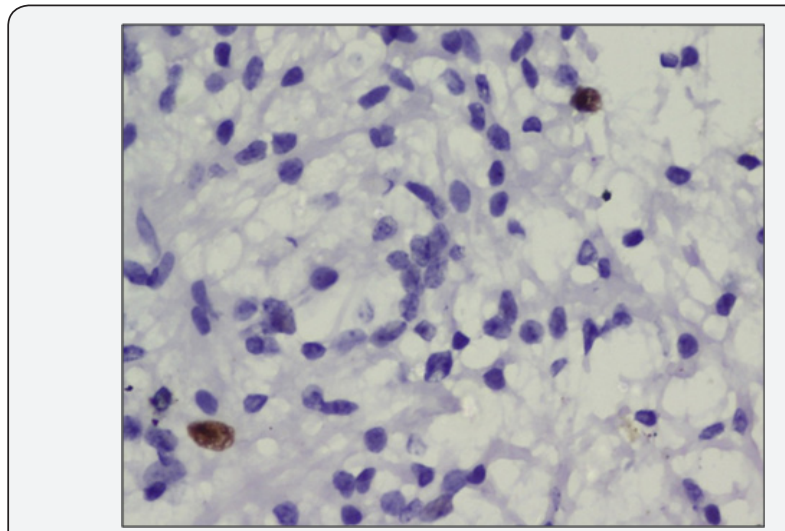

Figure 1: MIB-1 LI in Grade II astrocytoma showing few MIB-1 labeled nuclei. (MIB-1, x400).

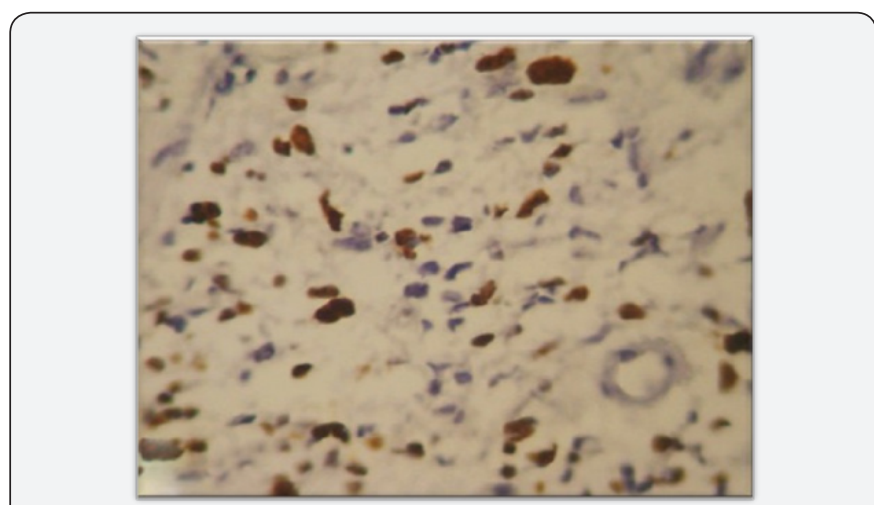

Figure 2: MIB-1 LI in Grade III astrocytoma showing many MIB1 labeled nuclei. (MIB-1, x400).

$\mathrm{P}$ values were obtained using Students unpaired $\mathrm{T}$ test. $P$ value of $<0.001$ was obtained between Grade II and Grade III astrocytomas which were statistically significant. Survival analysis was done, but no significant confines were identified for MIB-1 LI. Better survival rate was observed in younger individuals, but was not significant based on statistical outcome.

\section{Discussion}

The WHO classification of astrocytomas has limitations in predicting the clinical outcome and survival of patients. Literature studies have shown that proliferative index derived from MIB-1 LI provides more knowledge on the biological behaviour in various grades of astrocytomas directly impacting patient management and survival $[6,7]$.

The result obtained in our present study, showed that third decade was the most common age group in the study population. The male preponderance with respect to astrocytomas is universally recognized, so as in our study [8]. Astrocytomas were usually supratentorial in adults and infratentorial in infants and children as observed by Pant et al. [5].

In the present study, Grade II astrocytomas where mostly fibrillary pattern and only two cases with gemistocytic type was identified. This finding was similar to those seen in studies by Pal et al. [9] and Wahal et al. [10]. 
Histopathologic diagnosis based on WHO classification of astrocytomas has been challenging to distinctly differentiate tumor grades either due to limited tumor material or due to difficulty in identifying mitoses in $\mathrm{H}$ and E stained sections [4].

In our present study, MIB-1 LI was done to assess the proliferative activity in Grade II and Grade III astrocytomas as it is sometimes difficult based on morphology and mitosis to differentiate between these two grades [11].

Johannessen \& Torp [12] analysed and reviewed 16 studies which constituted a total of 915 patients demonstrating a substantial increase in MIB-1 LI with increasing grade of malignancy. As in our study, the reports demonstrated a mean of MIB-1 LI in Grade II and Grade III astrocytoma of approximately 3 and 12.

The statistical significance obtained in our study between Grade II and Grade III astrocytomas have been documented in various studies [2,13,14]. Rodrvguez et al. [15] and Hsu et al. [16] identified that Grade II tumors had significantly lower MIB1 LI compared to Grade III tumors. Arvinder et al. [17] study on gemistocytic astrocytomas found lower MIB-1 LI though they are classified as Grade II astrocytomas.

In a bivariant analysis done by Rodriguez- Pereira et al. [15] 19MIB-1 LI increased with age, histologic grade and a supratentorial location. Hence, the importance of the proliferation marker is influenced by many factors which reduce its value as an isolated prognostic parameter. Our study shows that MIB-1LI is dependent solely on the histologic grade and is independent of age and sex.

Most studies demonstrated positive correlations between MIB-1 LI, survival and recurrence. Paul et al. [18] found that gender, tumor location and radiotherapy had no significant association with survival. However, high MIB-1 predicted shorter survival and also an independent prognostic factor in Grade II astrocytomas.

Table 2: MIB-1 LIs of Grade II Astrocytomas in different studies.

\begin{tabular}{|c|c|c|}
\hline & No. of Cases & Mean value of MIB-1 LI \\
\hline Present study & 29 & 3.07 \\
\hline Khalid et al. [19] & 24 & 1.78 \\
\hline Sallinen et al. [20] & 8 & 6.26 \\
\hline Wakimoto et al. [14] & 19 & 3.8 \\
\hline Hilton et al. [21] & 96 & 1.15 \\
\hline
\end{tabular}

The mean MIB-1 LI in Grade II and Grade III astrocytomas in comparison with different studies are shown in (Table $2 \& 3$ ) [14,19-21].
Table 3: MIB-1 LI in Grade III Astrocytomas in different studies.

\begin{tabular}{|c|c|c|}
\hline & No. of Cases & Mean value of MIB-1 LI \\
\hline Present study & 21 & 12.04 \\
\hline Khalid et al. [19] & 20 & 13.47 \\
\hline Sallinen et al. [20] & 13 & 16.61 \\
\hline Wakimoto et al. [14] & 25 & 18.4 \\
\hline
\end{tabular}

A wide variety of factors were responsible for the differences in MIB-1 LI. These factors include fixatives used, technical issues with variety of detection procedures, dilutions of antibodies used, antigen retrieval procedures and finally interpretation of immune staining [14].

Grzy bicki et al. [22] conducted a inter observer variabilty study to assess the differences in MIB-1 LI and found that high levels limited the prognostic usefulness for patients with primary brain tumors. These key factors are important to be noted while planning the treatment options after considering MIB-1 LI in astrocytomas. MIB- 1 is an important clinical marker in astrocytomas, but with these shortcomings it is not reliable to use absolute cut-off values between different laboratories and it is also difficult to standardize it for prognostic purposes.

\section{Conclusion}

MIB-1 immuno staining worked well and yielded credible results in our study. Therefore, this marker when used in combination with clinical evaluation and tumor grade, provide a greater perspective in evaluating and strategic treatment planning with patients of astrocytomas.

\section{References}

1. Kleihues P, Cavenee WK (2000) World Health Organization Classification of Tumors. In: Kleihues P, Cavenee WK (eds.), Pathology and Genetics of Tumors of the Nervous System. ( $3^{\text {rd }}$ edn), IARC Press, Lyon, France, p. 314.

2. Ambroise MM, Khosla C, Ghosh M, Mallikarjuna VS, Annapurneswari S (2011) Practical value of MIB-1 index in predicting behavior of astrocytomas. Indian J Pathol Microbiol 54(3): 520-525.

3. El Atti RMA, Gabal HHA, Osman WM, Saad AS (2013) Insights into the prognostic value of DJ-1 and MIB-1 in astrocytic tumors. Diagn Pathol 8: 126.

4. Louis DN, Ohgaki H, Wiestler OD, Cavenee WK, Burger PC, et al. (2007) The 2007 WHO Classification of Tumours of the Central Nervous System. Acta Neuropathol 114(2): 97-109.

5. Pant I, Chaturvedi S, Jha DK, Kumari R, Parteki S (2015) Central nervous system tumors: Radiologic pathologic correlation and diagnostic approach. J Neurosci Rural Pract 6(2): 191-197.

6. Rathi KR, Radotra BD, Khosla VK (2007) Proliferative index in astrocytic tumours. Indian J Pathol Microbiol 50(4): 754-758.

7. Mahathi T, Neelima T, Krishna R (2014) Role of Ki-67 labeling index as an adjunct to the histopathological diagnosis and grading of astrocytomas. J Cancer Res Ther 10(3): 641-645. 
8. Muhamat NFE, Chandrasekaran K, Marks JC (2013) A retrospective audit of 200 cases of CNS tumours and their surgical management in a tertiary care centre. Ir J Med Sci 182(4): 697-701.

9. Pal AK, Chopra SK (1975) Intracranial space occupying lesions an analysis of 142 cases. Indian J Pathol Bacteriol 18(1): 8-15.

10. Wahal KM, Mohanty AK, Padam KA, Mahrotan RML (1981) Gliomas of astrocytic series: A review of 86 cases. Indian J Cancer 18(1): 37-40.

11. Prayson RA (2002) Cell proliferation and tumors of the central nervous system. Part 1: Evaluation of mitotic activity. J Neuropathol Exp Neurol 61(6): 501-509.

12. Johannessen AL, Torp SH (2006) The clinical value of Ki-67/MIB-1 labeling index in human astrocytomas. Pathol Oncol Res 12(3): 143147

13. Thotakura M, Tirumalasetti N, Krishna R (2014) Role of Ki-67 labeling index as an adjunct to the histopathological diagnosis and grading of astrocytomas. J Cancer Res Ther 10(3): 641-645.

14. Wakimoto H, Aoyagi M, Nakayama T, Nagashima G, Yamamoto S, et al. (1996) Prognostic significance of Ki-67 labeling indices obtained using MIB-1 monoclonal antibody in patients with supratentorial astrocytomas. Cancer 77(2): 373-380.

15. Pereira CR, Peñaranda JMS, Salvado MV, Sobrido MJ, Abraldes M, et al. (2000)Value of MIB-1 labelling index (LI) in gliomas and its correlation with other prognostic factors. A clinic pathologic study. J Neurosurg Sci 44(4): 203-209.

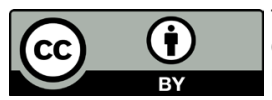

This work is licensed under Creative Commons Attribution 4.0 Licens DOI: 10.19080/JOJCS.2017.03.555625
16. Hsu DW, Louis DN, Efird JT, Hedley-Whyte ET (1997) Use of MIB-1 (Ki$67)$ immunoreactivity in differentiating grade II and grade III gliomas. J Neuropathol Exp Neurol 56(8): 857-865.

17. Avninder S, Sharma MC, Deb P, Mehta VS, Karak AK, et al. (2006) Gemistocytic astrocytomas: Histomorphology, proliferative potential and genetic alterations- a study of 32 cases. J Neurooncol 78(2): 123127.

18. McKeever PE, Strawderman MS, Yamini B, Mikhail AA, Blaivas M (1998) MIB-1 proliferation index predicts survival among patients with grade II astrocytoma. J Neuropathol Exp Neurol 57(10): 931-936.

19. Khalid H, Shibata S, Kishikawa M, Yasunaga A, Iseki M, et al. (1997) Immunohistochemical analysis of progesterone receptor and $\mathrm{Ki}-67$ labeling index in astrocytic tumors. Cancer 80(11): 2133-2140.

20. Sallinen PK, Haapasalo HK, Visakorpi T, Helén PT, Rantala IS, et al. (1994) Prognostication of astrocytoma patient survival by Ki-67 (MIB1), PCNA, and S-phase fraction using archival paraffin-embedded samples. J Pathol 174(4): 275-282.

21. Hilton DA, Love S, Baraber R, Ellison D, Sandeman DR (1998) Accumulation of p53 and Ki-67 expression do not predict survival in patients with fibrillary astrocytomas or the response of these tumors to radiotherapy. Neurosurgery 42(4): 724-729.

22. Grzybicki DM, Liu Y, Moore SA, Brown HG, Silverman JF, et al. (2001) Inter observer variability associated with the MIB-1 labeling index: high levels suggest limited prognostic usefulness for patients with primary brain tumors. Cancer 92(10): 2720-2726.

Your next submission with Juniper Publishers
will reach you the below assets
- Quality Editorial service
- Swift Peer Review
- Reprints availability
- E-prints Service
- Manuscript Podcast for convenient understanding
- Global attainment for your research
- Manuscript accessibility in different formats
( Pdf, E-pub, Full Text, Audio)
- Unceasing customer service
Track the below URL for one-step submission
https://juniperpublishers.com/online-submission.php

